\title{
THE INFLUENCE OF THE WORK ENVIRONMENT ON THE WORK MOTIVATION OF MUHAMMADIYAH HIGH SCHOOL TEACHERS IN MAKASSAR CITY
}

\author{
Muh. Ilyas Ismail ${ }^{1}$ \\ Wahidah $^{2}$ \\ Abd. Rahman Getteng ${ }^{3}$ \\ Lecturer of the Faculty of Tarbiyah and Teacher Training at UIN Alauddin Makassar ${ }^{1}$ \\ Postgraduate Alauddin State Islamic University Makassar ${ }^{2}$ \\ Postgraduate Lecturer at UIN Alauddin Makassar ${ }^{3}$ \\ daengilyas12@gmail.com¹,wahidahazura@gmail.com², rahmangetteng@gmail.com³
}

\begin{abstract}
This study discusses the influence of the work environment on the work motivation of Muhammadiyah high school teachers in Makassar City with the aim of examining the reality of the Muhammadiyah high school work environment in Makassar City, examining the reality of work motivation of Muhammadiyah high school teachers in Makassar City and examining the effect of the work environment on motivation. Muhammadiyah high school teacher work in Makassar City. This research is classified as quantitative research with ex post facto method. The data collection technique used is a questionnaire while the analysis technique used is descriptive statistics and inferential statistics with simple regression analysis. The results of this study indicate the reality of the working environment of Muhammadiyah high school in Makassar City from the results of data analysis the percentage of $77,4 \%$ of the expected criteria, the reality of work motivation of Muhammadiyah high school teachers in Makassar City from the results of percentage data analysis of $76,6 \%$, and there is an influence positive and significant relationship between work environment and work motivation of Muhammadiyah high school teachers in Makassar City is 49,3\%. So it can be concluded that the work environment is one of the factors that influence the work motivation of teachers. The implication of this research is that the school should be able to create a conducive work environment by fulfilling all the learning facilities and infrastructure needed by teachers in learning activities and in supporting the work of teachers so that each teacher can concentrate on carrying out their duties .
\end{abstract}

Keywords: Work Environment; Teacher Work Motivation; Muhammadiyah High School

\section{INTRODUCTION}

Motivation is the basic drive that moves a person to behave. This drive is in someone who moves to do something according to the impulse in him. Therefore, a person's actions are based on certain motivations containing themes according to the underlying motivation. ${ }^{1}$ Schools as educational institutions will certainly succeed and progress if they have teachers who have high motivation in carrying out their activities as teachers or educators. High teacher work motivation will be able to increase the

\footnotetext{
${ }^{1}$ Hamzah B. Uno, Motivation Theory and Its Measurement (Jakarta: Bumi Aksara, 2012), p. 1.
} 


\section{The Influence of The Work Environment on The Work Motivation of Muhammadiyah High School Teachers in Makassar City}

capabilities and productivity of teachers in performing the task, otherwise low teacher work motivation usually leads to ability and their work productivity will decline. ${ }^{2}$ Principal support in increasing teacher work motivation can be in the form of improving school facilities.

Observations of researchers on Muhammadiyah high school teachers in Makassar City saw that teachers in carrying out teaching tasks in schools were less responsible. This can be seen from the unpreparedness of teacher learning tools such as syllabus, annual programs, semester programs and face-to-face programs. The teacher's lack of initiative in carrying out work such as the teacher only provides learning tools if the supervisor comes to school to supervise the teacher. ${ }^{3}$

These phenomena occur cannot be separated from the lack of support for existing facilities in schools in the form of the availability of ATK (Office Stationery) in the form of paper which is always ready if the teacher wants to print learning tools. The limited facilities available at the school must of course be considered by the principal as the top leader. In teaching teachers of course also need adequate facilities in the classroom so that the teaching and learning process becomes effective and efficient. The hot air temperature in the classroom will certainly interfere with the learning process. As happened in SMA Muhammadiyah 2 Makassar, the facilities in the classroom have been provided with fans but the teacher and students still feel hot in the room. Apart from SMA Muhammadiyah 2, SMA Muhammadiyah 3, SMA Muhammadiyah 4, SMA Muhammadiyah 5 and 7 and SMA Muhammadiyah 9 still use fans in the classrooms. This is different from SMA Muhammadiyah 1 Unismuh and SMA Muhammadiyah 6 Makassar which have used air conditioning in classrooms. This condition will certainly greatly affect the learning process if the room is not conducive.

Principals can foster teacher motivation through the creation of a conducive work atmosphere. If the work atmosphere at school is conducive, the teacher will feel at home for a long time at school. Dra. Habibah said that what made her feel at home teaching at school was the atmosphere, good relations with colleagues and superiors, even though the salary was small, but because the relationship with teacher friends was very friendly, she felt grateful to meet good colleagues at school. ${ }^{4}$

Based on the above, this study will discuss the reality of the work environment and the reality of work motivation of Muhammadiyah high school teachers in Makassar City and the influence of the work environment on work motivation of Muhammadiyah high school teachers in Makassar City. The purpose of this study is to examine the reality of the work environment and work motivation of Muhammadiyah high school teachers in Makassar City and examine the influence of the work environment on work motivation of Muhammadiyah high school teachers in Makassar City.

${ }^{2}$ Erina Putri, " Teacher Work Motivation in the Implementation of Teaching Tasks at SMK Negeri Bukittinggi", Materials for Education Management, vol. 2 no. 1 (June 2014), p. 212.

${ }^{3}$ Wahidah (30 Years), Researcers, observation in SMA Muhamamdiyah 2 and 5 Makassar, Makassar, July 13-18, 2020.

${ }^{4}$ Dra. Habibah (45 Years), Teacher of SMA Muhammadiyah 5 Makassar, Interview, Makassar, 22 August 2020. 


\section{THEORITICAL REVIEW}

\section{A. Work Environment}

\section{Work Environment Theory}

OSHA (Occupational Safety \& Health Administration) defines the work environment as a workplace and other location where one or more employees work or are present in their work. The work environment includes not only the physical location, but also the equipment or materials used by employees during work. ${ }^{5}$ Meanwhile, according to Casson, the work environment is something from the work environment that makes or complicates work. Pleasing or difficult for them, including the factors of lighting, air temperature, ventilation, chairs and desks. ${ }^{6}$ Clark said that the work environment has a positive influence on employee motivation. Employee motivation is influenced by the ability of an employee to adapt to his work environment. ${ }^{7}$

The teacher's work environment is a school environment with everything around it. In schools, there are various factors that are included in the work environment of a teacher, including the physical environment of the school, the principal, other teacher colleagues, education staff, students, school facilities and infrastructure, non-physical conditions of the school environment and school bureaucracy. All of these work environment factors will directly or indirectly affect the work motivation of teachers.

\section{Types of Work Environment}

Sedarmayanti argued that broadly the work environment is divided into two, namely the physical work environment and the non-physical work environment. The physical work environment is all physical conditions that exist around the workplace that can affect employees either directly or indirectly. While the non-physical work environment is all conditions that occur related to work relations, both relationships with superiors and relationships with fellow co-workers or relationships with subordinates. ${ }^{8}$

AS Munandar stated that the physical work environment includes physical conditions, space, place, work equipment, type of work, superiors, co-workers, subordinates, people outside the company, company culture, policies, and institutional regulations. ${ }^{9}$ The dimensions of the physical work environment consist of several indicators, namely: noise, security lighting, the room air temperature, amenities, and decor in the workplace. ${ }^{10}$ While the dimensions of the non-physical work environment consist of several indicators, namely: peer relations at the same level, subordinate

${ }^{5}$ OSHA, Determination of Work Environment Relatedness (Washington DC: Unites States Department of Labor, December 28, 2020.

${ }^{6}$ Herbert N Casson, Company Efficiency (Jakarta: Erlangga, 2010), p. 123

${ }^{7} \mathrm{RE}$ Clark, Fostering the Work Motivation of Individuals and Teams, Permormance Improvement, 42 (3), p. 21-29.

${ }^{8}$ Sedarmayanti, Human Resource Management, Bureaucratic Reform and Civil Service Management (Cet. 5, Bandung: PT Refika Aditama, 2011), p. 26.

${ }^{9}$ AS. Munandar, Industrial and Organizational Psychology (Depok: University of Indonesia (UI) Press, 2010), p. 288.

${ }^{10}$ Sedarmayanti, Human Resource Management, Bureaucratic Reform and Civil Service Management, p. 26. 


\section{The Influence of The Work Environment on The Work Motivation of Muhammadiyah High School Teachers in Makassar City}

relations, superior relations, dynamic work climate, organizational culture, institutional policies and regulations. ${ }^{11}$ This physical work environment is in direct contact with the teacher, if everything is good, it will create a conducive, safe, comfortable, pleasant work environment. However, the non-physical work environment cannot be ignored.

\section{B. Teacher's Work Motivation}

\section{Undestanding Teacher Work Motivation}

According to Hamzah B. Uno, teacher work motivation is nothing but a process carried out to move teachers so that their behavior can be directed at real efforts to achieve the goals that have been set. ${ }^{12}$ Teacher work motivation according to Pupuh Fathurrohman and Aa Suryana is the impetus for a teacher to do work in order to achieve work goals according to the plan. ${ }^{13}$

Based on the above perspective, it can be concluded that teacher work motivation is an encouragement to the teacher to move and direct and do work according to the plan in order to achieve the goals that have been set. The goals that have been set are related to aspects of self-perception, views on work, need for appreciation, sincerity in work, awareness of the desire to move forward and expectations.

\section{Teacher's Work Motivation Function}

Teacher's work motivation function are encouraging people to act, motivation functions as a driving force or as a motor that provides energy (strength) to a person to perform a task. Motivation determines the direction of action, namely towards the realization of a goal or ideals. Motivation prevents deviation from the path that must be taken to achieve that goal. The clearer the goal, the clearer the path that must be followed. Motivation selects our actions, this means determining the actions that must be carried out, which are compatible, in order to achieve that goal by setting aside actions that are not useful for that goal. ${ }^{14}$

According to Nana Syaodih Sukmadinata, motivation has two functions, namely: firstly directional function, secondly activating and energizing function. Teacher work motivation serves to direct, activate and improve teacher activities. Giving motivation to teachers in order to complete their duties and responsibilities as educators will direct, activate, and improve the performance of the teacher.15 The function of the teacher's work motivation is as a driving force that encourages teachers to do the work that has been assigned, determine the direction of action in accordance with the set of goals that have been formulated, and select actions by setting aside activities that are not useful in completing the work.

\footnotetext{
${ }^{11}$ AS. Munandar, Industrial and Organizational Psychology, p. 288-289.

${ }^{12}$ Hamzah B. Uno, Motivation Theory and Its Measurement: Analysis in Education (Jakarta: PT Bumi Aksara, 2013), p. 72.

${ }^{13}$ Pupuh Fathurrohman \& Aa Suryana, Professional Teachers (Bandung: PT Refika Aditama, 2012) h. 63.

${ }^{14}$ M Ngalim Purwanto, Educational Psychology (Bandung: PT Remaja Rosdakarya, 2010), p.70.

${ }^{15}$ Nana Syaodih Sukmadinata, Psychological Foundation of the Educational Process (Bandung: PT Remaja Rosdakarya, 2009), p. 62.
} 


\section{Teacher's Work Motivation Indicator}

Pupuh Fathurrohman and Aa Suryana stated that the indicators used to measure the work motivation of teachers include proper remuneration, opportunities for promotion, gaining recognition, and job security.16 Meanwhile, Hamzah B. Uno stated that indicators of teacher work motivation appear through responsibility in doing work, achievements achieved, self-development, and independence in acting.17

Teacher work motivation is measured from two dimensions, namely internal motivation and external motivation. Internal motivation includes responsibility in carrying out tasks, carrying out tasks with clear targets, independence in acting, having feelings of pleasure at work, and achievements. External motivation includes trying to meet needs, opportunities for promotion, gaining recognition, and working with the hope of getting a decent reward.

\section{RESEARCH METHODOLOGY}

This research uses quantitative research with ex post facto method. ${ }^{18}$ The population in this study amounted to 142 people Muhammadiyah high school teachers in Makassar City. The sampling technique used in this study was proportionate random sampling with a total sample of 105 people and the data collection technique was a closed questionnaire. The data analysis technique used is the analysis of s statistical descriptive and analytical statistical inferential.

\section{RESULT AND DISCUSSION}

\section{A. Reality of Muhammadiyah High School Work Environment in Makassar City}

Data from research on the work environment of Muhammadiyah SMA in Makassar City which was obtained from 105 respondents through a questionnaire which was then processed through SPSS version 21 obtained the mean, standard deviation, range, minimum, maximum, and the total number of scores as follows:

Descriptive Statistics

\begin{tabular}{|c|c|c|c|c|c|c|c|}
\hline & $\mathrm{N}$ & Range & Minimum & Maximum & Sum & Mean & $\begin{array}{c}\text { Std. } \\
\text { Deviation }\end{array}$ \\
\hline Work Environment & 105 & 28 & 37 & 65 & 5524 & 52.61 & 6.230 \\
\hline Valid N (listwise) & 105 & & & & & & \\
\hline
\end{tabular}

Source of research data: Results of SPSS analysis version 21

Based on this table shows that the working environment $\left(\mathrm{X}_{1}\right)$ SMA Muhammadiyah in Makassar from 105 respondents have values mean 52.61, standard

\footnotetext{
${ }^{16}$ Nana Syaodih Sukmadinata, Psychological Foundations of the Educational Process , p. 64.

${ }^{17}$ Hamzah B. Uno, Motivation Theory and Its Measurement: Analysis in Education, p. 72.

${ }^{18}$ Sulaiman Saat and Sitti Mania, Introduction to Research Methodology: A Guide for Beginner Researchers (Cet. I; tt: SIBUKU Publisher, 2018), p. 113.
} 
deviation of 6.230 , the range of 28 due to score a maximum of 65 and score a minimum of 37 , as well as the total score for 5525 .

The reality of the working environment of SMA Muhammadiyah in Makassar City can be known by dividing the total score by the number of criteria scores. The total score for the work environment variable is 5525 . While the total score for the criteria is $105 \times 17 \times 4=7140$, so $5525 / 7140=0.774$. Thus, the percentage of the working environment of SMA Muhammadiyah in Makassar City is $77,4 \%$ of the expected criteria.

\section{B. Reality of Work Motivation of Muhamamdiyah High School teachers in Makassar City}

Data from research on the work environment of SMA Muhammadiyah in Makassar City obtained from 105 respondents through a questionnaire which was then processed through SPSS version 21 obtained the mean, standard deviation, range, minimum, maximum, and the total number of scores as follows:

\section{Descriptive Statistics}

\begin{tabular}{lccccccc}
\hline & N & Range & Minimum & Maximum & Sum & Mean & Std. Deviation \\
\hline Teacher Work & 105 & 22 & 26 & 48 & 3860 & 36.76 & 4.734 \\
Motivation & 105 & & & & & & \\
Valid N (listwise) & & & & & & \\
\hline
\end{tabular}

Source of research data: Results of SPSS analysis version 21

Based on the table, it shows that the teacher's work motivation (Y) at SMA Muhammadiyah in Makassar City from 105 respondents has a mean value of 36.76, a standard deviation of 4734, a range of 22 because the maximum score is 48 and the minimum score is 26 , and the total score is equal to 3860 .

The reality of the work motivation of Muhammadiyah high school teachers in Makassar city can be determined by dividing the total score by the number of criteria scores. The total score obtained for the work environment variable is 3860 . While the total score for the criteria is $105 \times 12 \times 4=5040$, so $3860 / 5040=0.766$. Thus, the percentage of work motivation of Muhammadiyah high school teachers in Makassar City is $76,6 \%$ of the expected criteria.

\section{The Influence of Work Environment on Work Motivation of Muhammadiyah High School Teachers}

The results of the analysis based on simple linear regression obtained the regression equation $\mathrm{Y}=8,688+0,534 \mathrm{X}$. This indicates that if the work environment moved up one unit, work motivation of teachers can be predicted to increase by 0,534 $(53,4 \%)$ at constant 8.688 .

The magnitude of the influence of the work environment on teacher work motivation can be seen in the results of the determination test through SPSS version 21 in the following table: 
Model Summary ${ }^{b}$

\begin{tabular}{cccccc}
\hline Model & R & R Square & $\begin{array}{c}\text { Adjusted R } \\
\text { Square }\end{array}$ & $\begin{array}{c}\text { Std. Error of } \\
\text { the Estimate }\end{array}$ & Durbin-Watson \\
\hline 1 & .702 a & .493 & .488 & 3.387 & 1,689 \\
\hline \multicolumn{5}{c}{ Research data source: SPSS 21 analysis results }
\end{tabular}

Based on the SPSS output table above, there is an $R$-Square coefficient of determination of $0.493(49.3 \%)$. This shows that $49.3 \%$ of the influence of the work environment on the work motivation of teachers. Thus the magnitude of the influence of the work environment on the work motivation of Muhammadiyah high school teachers in Makassar City is $49.3 \%$ and the remaining $50.7 \%$ is influenced by other factors.

The results of this study indicate that the work environment, both physical and non-physical environments, contributes to the work motivation of teachers, although the effect is not too large. The results of this study support the findings of Gerishon ${ }^{19}$ through the results of his research which shows that the work environment has an influence on teacher job satisfaction. Although Gerishon's research does not directly affect teacher work motivation, the work environment will ultimately lead to an increase in teacher work motivation in order to achieve teacher job satisfaction. The results of this study also support the findings of Cristaabella P Bushira ${ }^{20}$ which shows that the work environment has an impact on employee performance. This shows that the work environment has an impact on employees by revealing that employees will improve their performance if work environment problems can be overcome such as work environment flexibility, work disturbances, supervisory interpersonal relationships with subordinates, the presence of work assistance, performance feedback and intensive improvement in the organization so that motivate employees to do their jobs.

\section{CONCLUSION}

The working environment of SMA Muhammadiyah in Makassar City is quite conducive with a percentage of $77,4 \%$ of what is expected and the work motivation of teachers is also quite high with a percentage of $76,6 \%$ of what is expected although there are still $22,6 \%$ and $23,4 \%$ that need to be done. improved. The effect of the work environment on the work motivation of Muhammadiyah high school teachers in Makassar City is $49,3 \%$ and the remaining 50,7\% is influenced by other factors.

${ }^{19}$ Gerishon Mbogo, “The Influence of Work Environment on Job Satisfaction Among teachers in public primary schools programs in Nembure division, Embu west district, Kenya", Thesis (Kenya: University of Nairobi, 2015), p. 39-40.

${ }^{20}$ Cristabella P Bushiri, "The Impact Of Working Environment On Employees' Performance: The Case Of The Institute Of Finance Management In Dar es Salaam Region", Thesis, (Tanzania: University of Tanzania, 2014), p. 49-55 


\section{REFERENCE}

Bushiri, Cristabella P, “ The Impact Of Working Environment On Employees' Performance: The Case Of Institute Of Finance Management In Dar Es Salaam Region", Thesis, Tanzania: University of Tanzania, 2014.

Casson, Herbert N, Corporate Efficiency, Jakarta: Erlangga, 2010.

Clark, RE, Fostering the Work Motivation of Individuals and Teams, Permormance Improvement, 42 (3).

Fathurrohman Pupuh \& Aa Suryana, Professional Teachers, Bandung: PT Refika Aditama, 2012.

Mbogo, Gerishon, “The Influence of Work Environment on Job Satisfaction Among teachers in public primary schools programs in Nembure division, Embu west district, Kenya", Thesis, Kenya: University of Nairobi, 2015.

Munandar, AS, Industrial and Organizational Psychology, Depok: University of Indonesia (UI) Press, 2010.

OSHA, Determination of Work Environment Relatedness (Washington DC: Unites States Department of Labor, 2020.

Purwanto, M Ngalim, Educational Psychology, Bandung: PT Teen Rosdakarya, 2010.

Putri, Erina "Teacher's Work Motivation in the Implementation of Teaching Tasks at SMK Negeri Bukittinggi", Materials for Education Management, vol. 2 no. June 1, 2014.

Saat, Sulaiman and Sitti Mania, Introduction to Research Methodology: A Guide for Beginner Researchers, Cet. I; tt: SIBUKU Publisher, 2018.

Sedarmayanti, Human Resource Management, Bureaucratic Reform and Civil Servant Management, Bandung: PT Refika Aditama, 2011.

Sukmadinata, Nana Syaodih, Psychological Foundations of the Educational Process, Bandung: PT Remaja Rosdakarya, 2009.

Uno, Hamzah B, Motivation Theory and Its Measurement: Analysis in Education, Jakarta: PT Bumi Aksara, 2013. 